\title{
WADAH AKTIVITAS DAN TAMAN BACAAN SEBAGAI THIRD PLACE DI KAWASAN KWITANG
}

\author{
Stanly Manuel ${ }^{1)}$, Rudy Trisno ${ }^{2)}$ \\ 1)Program Studi S1 Arsitektur, Fakultas Teknik, Universitas Tarumanagara, Stanstand12@gmail.com \\ 2)Program Studi S1 Arsitektur, Fakultas Teknik, Universitas Tarumanagara, rudyt@ft.untar.ac.id
}

Masuk: 13-07-2020, revisi: 23-07-2020, diterima untuk diterbitkan: 05-09-2020

\begin{abstract}
Abstrak
Pada dasarnya masyarakat adalah makhluk sosial yang membutuhkan interaksi antar sesama. Kawasan Kwitang merupakan salah satu kawasan permukiman yang padat dan sibuk di Jakarta. Akibatnya muncullah sikap individualis karena kesibukan dan rutinitasnya yang kadang membuat mereka lupa pentingnya bersosialisasi dan beristirahat dari kesibukannya, ruang pada kawasan sedikit bagi mereka untuk melakukan kegiatan selain rutinitas seperti bersosialisasi atau melakukan hubungan timbal balik. Sebagaimana tentu membutuhkan kehadiran ruang ketiga yang dapat menjadi solusi masyarakat untuk melepas penat dari rutinitasnya dan saling bersosialisasi antar sesama. Dari beragam potensi dan masalah yang ada, Wadah aktivitas dan taman bacaan masyarakat bertujuan mampu mengakomodasi atau mewadahi aktivitas masyarakat dengan berusaha memenuhi kebutuhan dasar masyarakat seperti sosialisasi dan hubungan timbal balik antar orang dan menjadi karakter kawasan yang berupa penjualan bukubukunya. Pendekatan dengan tahap observasi, survei, kemudian dilanjutkan dengan analisis lokasi serta potensi, konsep desain bangunan sampai pada hasil akhir berupa bangunan. Program diolah dengan metode form and function runs together, cross programming, serta metode desain berupa kontinuitas dan welcoming space pada proyek. Kesimpulan pada proyek bangunan ini adalah dengan berusaha memberikan ruang ketiga pada kawasan Kwitang agar manusia dapat berinteraksi, dan timbal balik maupun dengan lingkungannya.
\end{abstract}

Kata kunci: Bersosialisasi; Kwitang; Third place

\begin{abstract}
Basically, a human is a social being that needs to have interaction one and another. Kwitang as one of the busiest and most densely populated areas in Jakarta As a result, basic human needs that are not met causes the people in the Kwitang area to have a business in front of their homes. However, nowadays people getting to be more individualistic because of their business and routine. They easily forget the importance of their social life and taking care of themselves. It makes the needs of existence the Third Place higher in society. The existence of the third becomes a solution for people to escape from their routine and have a better social life. Considering the problems and potency in the area, Literature Park and Activity Hub is designed to accommodate and solve people's problems by trying to meet the basic needs of the community such as socialization and mutual relations between people and become a character in the form of selling books. The program will be processed in the form of a method approached with observation and survey then starting from location analysis until product of architechture. Using Form runs Together, and cross programming method, and also design method in the form of continuity and welcoming space on the project. So the conclution is the design of this building could provide a third space in Kelurahan Kwitang so humans can interact to help the process of socialization between humans and their environment. Therefore, this project and concept could be implemented and create the Third Place in Kwitang.
\end{abstract}

Keywords: Kwitang; Socialize; Third place 


\section{PENDAHULUAN}

\section{Latar Belakang}

Kwitang, merupakan Kelurahan dari Kecamatan Senen, Jakarta Pusat. Pada sejarahnya, Kwitang merupakan kawasan yang dikenal dengan penjualan buku-bukunya. Buku yang diperdagangkan pun bermacam-macam, baik buku baru, bekas, hingga yang sudah langka. Jenis topik buku-buku itu juga beragam, mulai dari politik, sastra, ekonomi, hingga untuk anak (Lihat Gambar 1).

Namun semenjak pemerintah Jakarta Pusat melakukan penertiban pada pedagang buku ini di tahun 2007 keadaan di Kwitang tak lagi sama, dikarenakan berjualan di badan jalan merupakan pelanggaran. Namun hal tersebut tak mengurangi jumlah pengunjung yang datang untuk membeli buku sampai dengan sekarang (Prasetya, 2019). Kawasan Kwitang merupakan kawasan yang menengah ke bawah, dan berdasarkan observasi dan data yang di dapat, bahwa kawasan Kwitang merupakan salah satu kawasan yang padat penduduk di jakarta. Sehingga seiring dengan perkembangan kota Jakarta banyak orang harus mengadu nasib untuk mendapat penghasilan tambahan, namun yang sangat disayangkan adalah banyaknya warga yang datang untuk mencari pekerjaan tanpa memiliki sesuatu kemampuan tertentu ataupun mereka tidak ketahui kalau nantinya hendak bekerja dimana, sehingga banyak di antara mereka yang berjualan pada rumah masing-masing. Seperti pada garasi rumah dijadikan untuk menjual makanan, usaha laundry, salon, dan lainnya (Lihat Gambar 2).
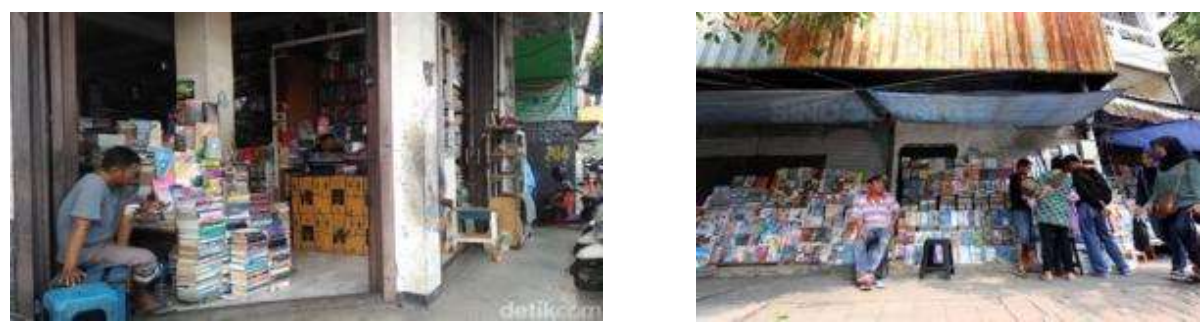

Gambar 1. Perdagangan Buku Sumber: Google Image, 2020
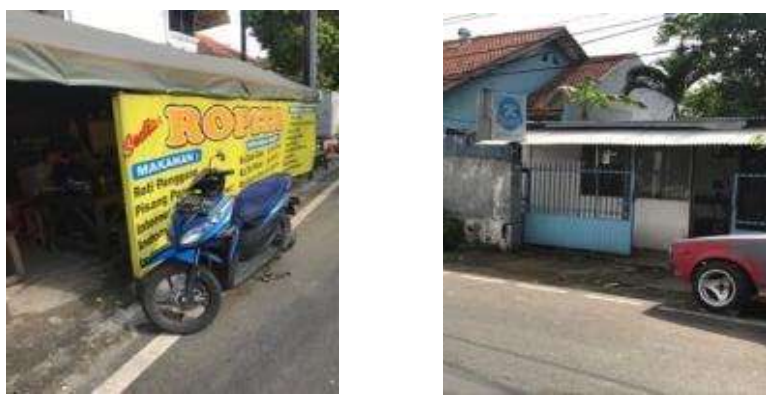

Gambar 2. Perdagangan di Rumah

Sumber: Dokumentasi Pribadi, 2020

Fenomena terdapatnya sifat hubungan antar personal yang lebih dititik beratkan pada pertimbangan keuntungan secara ekonomis, sehingga perlahan terbentuk pergantian tata nilai pada kehidupan masyarakat sehingga hal tersebut mengakibatkan munculnya sikap individualisme antar individu, mayoritas warga tidak mau keluar rumah tanpa ada keperluan, ataupun melakukan interaksi sosial antar warga, dan tidak sedikit juga dari mereka yang hanya melakukan rute pulang-pergi; dari rumah (first place) ke tempat kerja (second place) setiap harinya, dikarenakan tidak adanya ruang ketiga (third place) sebagai tempat peralihan yang dapat digunakan bersama sehingga dapat melepas penat, ataupun mereka dapat melakukan interaksi sosial antar manusia pada kawasan tersebut, yang dalam hal perancangan ini third place di fokuskan kedalam perancangan ruang terbuka dan lainnya. 
Oleh karena itu dengan kehadiran wadah sebagai third place kawasan untuk membangkitkan aktivitas, kreativitas dan lainnya sisesuaikan dengan kondisi sosial yang ada. Pemilihan program yang mendukung diharapkan dapat saling memberi hubungan timbal balik antar masyarakat dan lingkungannya, serta menjadikan kawasan yang hidup dan juga mengimplementasikan unsur penjualan buku selaku karakter pada kawasan kwitang.

\section{Rumusan Permasalahan}

Adapun rumusan permasalahan dari latar belakang diatas sebagai berikut: (1) Individualisme yang terjadi; (2) Rutinitas yang terjadi yang membuat masyarakat menjadi individualis.

\section{Tujuan}

Tujuan pada penelitian ini adalah: (1) Mengakomodasi/ mewadahi kegiatan sosial berdasarkan kebutuhan dasar masyarakat dengan menyatukan segala aktivitas mereka saat ini, yaitu untuk saling berinteraksi sosial atau hubungan timbal balik; (2) program yang dibutuhkan untuk menunjang aktivitas dan memenuhi kebutuhan masyarakat pada kawasan Kwitang serta mengimplementasikan penjualan buku yang menjadi kekhasan kawasan.

\section{Manfaat}

Manfaat dari proyek, yaitu: (1) Menjadikan proyek ini sebagai wadah atau tempat kegiatan bagi warga supaya mereka dapat mempunyai mutu hidup yang lebih baik; (2) menjadi ruang publik baru sebagai tempat untuk dapat saling berinteraksi; (3) sebagai tempat penjualan buku sebagai ciri khas kawasan.

\section{KAJIAN LITERATUR}

Memahami third place, teori-teori yang sudah ada dikaji kemudian dipahami agar mendapatkan pemahaman mengenai tema tersebut. Kajian terhadap teori menjadi salah satu dari kegiatan yang penting dalam merancang third place dari sumber yang ada sehingga dapat mendefinisikan bangunan yang akan dibuat.

\section{Third Place}

Bersumber pada teori Ray Oldenburg tentang The Third Place, bahwa dalam merancang Third Place dibutuhkan kriteria dan prinsip penting yang wajib dipenuhi, seperti Istilah Third Place adalah istilah yang umum untuk menunjukan tempat-tempat publik yang diadakan secara senantiasa, sukarela, informal, atau seperti berkumpul bersama keluarga atau teman (Oldenburg, 1999). Dalam buku The great good Place, Ray Oldenburg menyatakan karakteristik ruang ketiga:

a. On neutral Ground, Agar kota dan lingkungannya dapat menawarkan keberagaman, harus ada tempat yang netral untuk orang dapat berkumpul. Tempat dimana individu dapat datang dan pergi sesuka mereka, dan dimana semua merasakan kenyamanan.

b. Leveler (tempat yang menyamaratakan), Atau tempat yang inklusif, memberikan kesempatan orang berkumpul bersama tanpa tujuan, lebih tinggi, atau lebih rendah.

c. Conversation, yaitu bahwa aturan tentang percakapan cenderung ada di tempat ketiga. Perckapan pada tempat ketiga juga melengkapi proses leveling, percakapan pada tempat ketiga juga melengkapi proses leveling.

d. Accessibility and Accommodation, Tempat ketiga yang mudah diakses serta memberikan layanan terbaik dan terlengkap tempat dimana seorang dapat pergi sendiri.

e. The Regulars, Tempat ketiga ada ketika orang tepat ada di sana untuk menjadi hidup dan berkarakter

f. A low profile, Tempat ketiga lebih cenderung tidak mengesankan orang yang belum tahu.

g. Mood is playful, Semangat bersenang-senang, rasa diterima menjadi elemen yang penting.

h. Home away from home, Ruang ketiga terbangun dari komunitas, menimbulkan sense of community sendiri atau memenuhi kebutuhan manusia dalam neighbourhood. 
Kegiatan sosial dapat dimaksud bagaikan aktivitas yang memerlukan kedatangan orang lain. Aktivitas bisa berbentuk tatap muka, pembicaraan, ataupun kegiatan raga yang lain semacam bermain ataupun berolahraga (Zhang \& Lawson, 2009).Penindakan ruang publik yang kreatif dapat menunjang terjadinya kegiatan sosial antara orang- orang yang tidak saling mengenal. Suatu perencanaan ruang publik bisa dikatakan sukses apabila bisa menampung kegiatan publik secara fungsional, mempunyai aksesibilitas yang mudah, aman serta terjalin interaksi sosial yang baik di dalamnya. Third Place merupakan hal yang penting dalam membuat suatu komunitas dalam sebuah lingkungan.

Menurut buku The great good Place oleh Ray Oldenburg (1999), menyatakan bahwa ruang ketiga memiliki prinsip:

a. Kesamaan yang Tak Terbantahkan/ Irrefutable commonality, dimana orang akan memilih sendiri komunitas berdasarkan pada kesamaan yang tak terbantahkan itu, atau kurangnya komunitas itu.

b. Tempat dimana orang dapat bersosialisasi/ Locations where people interact, salah satu ciri khas komunitas yang berkembang adalah percakapan atau interaksi.

c. Unifying activity /generally low-effort or widely attractive, membawa orang masuk dengan cara termudah untuk mendapatkan dan membantu mereka membangun rutinitas, dan memupuk rasa kebersamaan.

\section{Faktor yang Mempengaruhi Ruang Publik}

Dalam merancang ruang publik, penting bagi sebuah kota yang menciptakan ruang sosial serta memberikan orang sebuah peluang untuk berkumpul dan terlibat dalam sebuah komunitas (Lihat Gambar 3). Berdasarkan (Project for Public Spaces) bahwa terdapat faktor yang mempengaruhi ruang publik, yaitu:

a. Access \& Linkages, Ruang publik mengacu pada area atau tempat mudah dicapai dan dilewati, terlihat baik dari kejauhan ataupun dari dekat, tanpa memandang tingkatan sosial, ras, dan lainnya.

b. Comfort \& Image, ruang yang aman, nyaman serta mengekspresikan dirinya dengan baik. Kenyamanan mencakup kenyamanan, keselamatan, kebersihan.

c. Uses \& Activities, Aktivitas adalah dasar, ada alasan mengapa orang mengunjungi di tempat tersebut, dan mengapa mereka terus kembali. Mereka juga yang membuat tempat unik.

d. Sociability, merasa nyaman berinteraksi dengan orang asing, merasakan rasa tempat yang lebih kuat atau keterikatan dengan komunitas mereka dan ke tempat yang mendorong jenis kegiatan sosial.

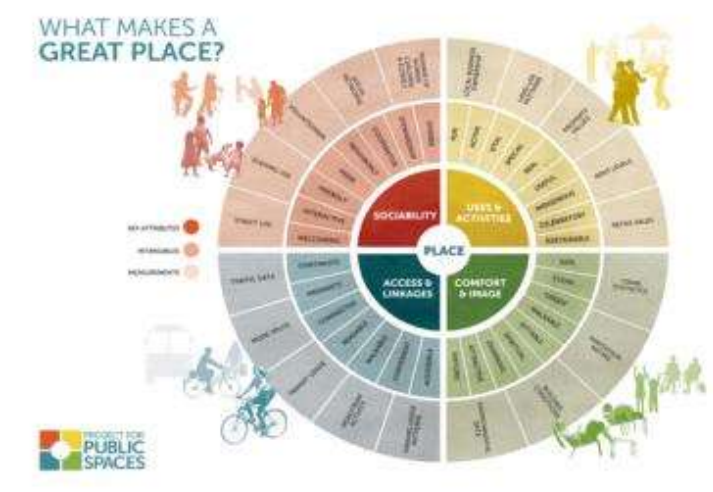

Gambar 3. Faktor yang mempengaruhi Ruang Publik Sumber: PPS (Project for Public Space) 
Walaupun terdapat banyak metode lain buat jadi kreatif di ruang publik, wajib jadi peninggalan yang bernilai di mana kota menganut konsep yang menghasilkan ruang yang lebih bersemangat dan ramah untuk digunakan seluruh orang. Ini dapat menjadi metode yang menghasilkan area yang lebih positif untuk orang.

\section{Perwujudan Perilaku Individualis Dalam Sikap dan Perilaku}

Aktivitas tiap masyarakat kota dalam tempo yang besar dapat mengurangi atensi terhadap sesamanya. Apabila perihal ini berlebihan, hendak memunculkan watak acuh tidak acuh ataupun kurang memiliki toleransi sosial ataupun rasa individualisme (Bintarto, 1984).

\section{Hubungan Interaksi Sosial dan Ruang Publik}

Berkaitan dengan interaksi sosial yang terjadi pada ruang publik (Gehl, 2011), membagi kegiatan luar ruang pada ruang publik (Public Space) menjadi tiga kategori yaitu;

a. Kegiatan berdasarkan atas kebutuhan/keperluan sehari-hari (necessary activities), seperti kegiatan belanja, pergi bekerja, ke sekolah dan sebagainya.

b. Kegiatan pilihan (optional activities) merupakan kegiatan yang lebih bersifat leisure atau memanfaatkan waktu luang seperti berjalan-jalan, menikmati pemandangan dan sebagainya.

c. Kegiatan sosial (social activities), merupakan kegiatan yang bersifat interaktif yaitu berhubungan dengan orang lain, seperti memberi salam, bercakap atau kegiatan bersama atau merupakan kontak pasif seperti mendengarkan atau melihat orang lain.

Kegiatan interaksi tersebut bersifat rutin dan terjadi dalam ruang publik di mana semua orang dapat menggunakan ruang tersebut dalam kapasitas yang sama dan dengan rutinitasnya, interaksi yang terjadi antar penggunanya dapat memiliki nilai yang lebih. Semakin tinggi kontak yang terjadi semakin hidup kegiatan suatu kota dan sebaliknya. Dengan sifat kegiatan tersebut tentunya akan membentuk suatu karakter ruang interaksi yang tidak sebatas sebagai wadah akan tetapi lebih menjadi tempat yang memiliki makna, yaitu Third place.

\section{Pasar Sebagai Kebutuhan Ruang Publik}

Suatu pasar, menurut Lewis Mumford, terjadi untuk mewadahi berlangsungnya 3 aktivitas utama: membeli, menyimpan, serta distribusi komoditas. Ketiga aktivitas ini sekalian pula menjadi komoditas utama yang ditawarkan dari kehadiran pasar itu sendiri: perdagangan, riba, dan jasa. Dalam aplikasi tiap harinya, pasar juga menjadi ruang yang dapat dikunjungi berbagai kalangan, Adapun jenis-jenis pasar seperti berikut:

a. Pasar Tradisional, Suatu tempat yang merupakan tempat bertemunya para penjual serta pembeli dan ada transaksi jual beli secara langsung serta pada umumnya terjalin proses tawar-menawar (Wikipedia).

b. Pasar Modern, Perbandingan antara pasar modern serta pasar tradisional tidak berbeda jauh, tetapi pasar modern tidak ada penjual serta pembeli yang bertransaksi secara langsung, melainkan konsumen ataupun pembeli memandang label harga yang ada dalam benda tersebut, pelayanannya dilakukan secara mandiri (Dwiyantoro, 2019).

Pasar yang ingin dibentuk adalah pasar yang tetap mempertahankan ciri tradisional yang berada di kawasan Kwitang, yaitu dengan adanya transaksi jual-beli secara langsung dan proses tawarmenawar. Menjadi daya tarik yang membedakan pasar tradisional, dengan modern yang cenderung kurang memperhatikan sosialisasi dalam berkomunikasi antar manusia.

\section{Taman Bacaan}

Taman Bacaan Masyarakat merupakan suatu tempat untuk menumbuhkan hasrat baca kepada warga yang ada di lingkungan taman bacaan tersebut dan taman bacaan masyarakat termasuk dalam kategori perpustakaan umum. Namun Taman Bacaan sifatnya lebih informal dan cakupan tidak 
terlalu luas dibanding perpustakaan yang sifatnya lebih formal dan cakupannya lebih luas. Menurut Buku pedoman Pengelolaan Taman Bacaan Masyarakat, Taman bacaan mempunyai fungsi yang terdiri dari fasilitas pendidikan, hiburan (rekreatif) untuk memanfaatkan waktu senggang serta mendapat informasi yang dibutuhkan baik mengenai masalah yang langsung berhubungan dengan permasalahan pembelajaran ataupun tidak berhubungan dengan pembelajaran.

\section{METODE}

Dengan berbagai literatur pendukung yang berkaitan dan latar belakang masalah dalam pembahasan topik yang terkait. Tahapan penelitian antara lain:
a. Analisis Lokasi serta potensinya
b. Analisa Tapak Terpilih
c. Usulan Aktivitas dan Program Bangunan
d. Analisis perancangan berupa Gubahan Massa, Konsep desain bangunan
e. Modul semi permanen
f. Modul kios semi permanen
g. Zoning Massa
h. Materialitas,
i. Bentuk Rancangan berupa desain eksterior dan interior bangunan.

Dalam membuat sebuah perancangan berdasarkan kebutuhan yang dapat menajdi sebuah wadah aktivitas pada kawasan Kwitang dan taman Bacaan yang merupakan sebuah karakteristik sebuah kawasan yang dibentuk dari beberapa metode perancangan untuk membuat sebuah bangunan yang berfungsi sebagai third place pada kawasan, sebagai berikut:

a. Perancangan Form and Function Runs Together

Konsep desain yang bekerja secara bersamaan antara fungsi dan bentuk; dapat dimulai dari analisis program, ataupun dapat dimulai dari konsep desain bentuk. Namun meskipun dapat berjalan sendiri-sendiri, keduanya masih memiliki hubungan yang kuat dan ada timbal balik serta tetap menjadi satu-kesatuan dalam proyek arsitektur (Trisno \& Lianto, 2019).

b. Perancangan Cross-Programming

Pada proses perancangan, metode yang digunakan adalah metode perancangan Crossprogramming yang terinspirasi dari ide konsep perancangan milik Bernard Tschumi. Merupakan kedua program yang berbeda namun disatukan pada satu zona sehingga mengatasi individualisme dan menimbulkan keramaian pada saat bersamaan agar orang dapat saling interaksi (Tschumi).

c. Desain Kontinuitas

Adapun persepsi visual yang terkait dengan arsitektur adalah persepsi teori Gestalt, (Rooks and Wilson, 2000). Melihat adanya kontinuitas dari suatu bentuk sehingga tidak terputus ditengahtengah, namun justru keseluruhan yang ada pada bentuk dapat terlihat dari konsistensi keberlanjutan bentuk tersebut.

\section{DISKUSI DAN HASIL}

\section{Analisis Lokasi dan Potensi}

Kwitang, merupakan Kelurahan dari Kecamatan Senen, Jakarta Pusat, terletak di antara Jalan Senen Raya dan Jalan Kwitang Raya (Lihat Gambar 4). Seperti pada survei yang dilakukan pada sebagian besar kawasan merupakan perumahan dengan zonasi kuning, namun dijadikan tempat berjualan pada zonasi itu (lihat Gambar 5). 


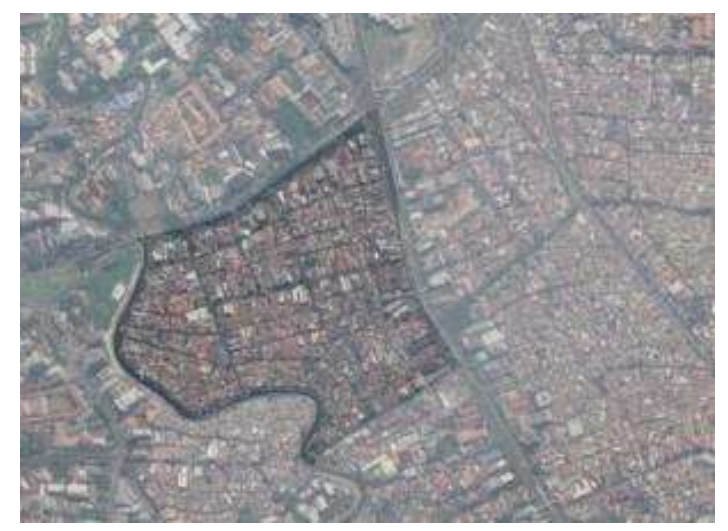

Gambar 4. Kawasan Kwitang

Sumber: Google maps

Pada hasil dan analisis yang dilakukan dengan cara mengumpulkan data kawasan dari karakter, masalah dan potensi yang berada pada lokasi kawasan Kwitang. Memilih tapak berdasarkan kebutuhan ruang, berada pada lokasi yang dekat dengan masyarakat, memudahkan akses pencapaian dari warga (walkable distance) serta nodes berupa titik temu yang sengaja atau tidak sengaja terbentuk pada kawasan itu adalah pasar dalam Kwitang yang dapat menjadi potensi third place pada kawasan yaitu pada pasar dalam Kwitang (Lihat Gambar 6). Penerapan tapak diwujudkan pada bentuk dan pola berdasarkan kondisi eksisting pada tapak adalah ditengah-tengah pusat masyarakat berkumpul. Berpotensi untuk mewujudkan gagasan mengenai pendorongan kegiatan sehingga kawasan menjadi hidup (Lihat Gambar 5). Proyek memberikan ruang terbuka hijau pada kawasan, karena tidak adanya ruang terbuka hijau atau ruang terbuka yang dapat dipakai bersama pada kawasan (Lihat tabel 1), berdasarkan tabel dari badan pusat statistik kota Jakarta pusat bahwa tidak ada keberadaannya ruang terbuka pada kawasan Kwitang dan menyediakan sarana edukasi berupa workshop pada proyek karena Seperti yang dibutuhkan masyarakat kawasan Kwitang pada forum Musrenbang (Musyawarah Perencanaan Pembangunan) bahwa usulan kegiatan tersebut merupakan usulan yang sifatnya pendidikan (Remaja Kwitang Manfaatkan Forum Musrenbang, 2019) (Lihat Gambar 7).
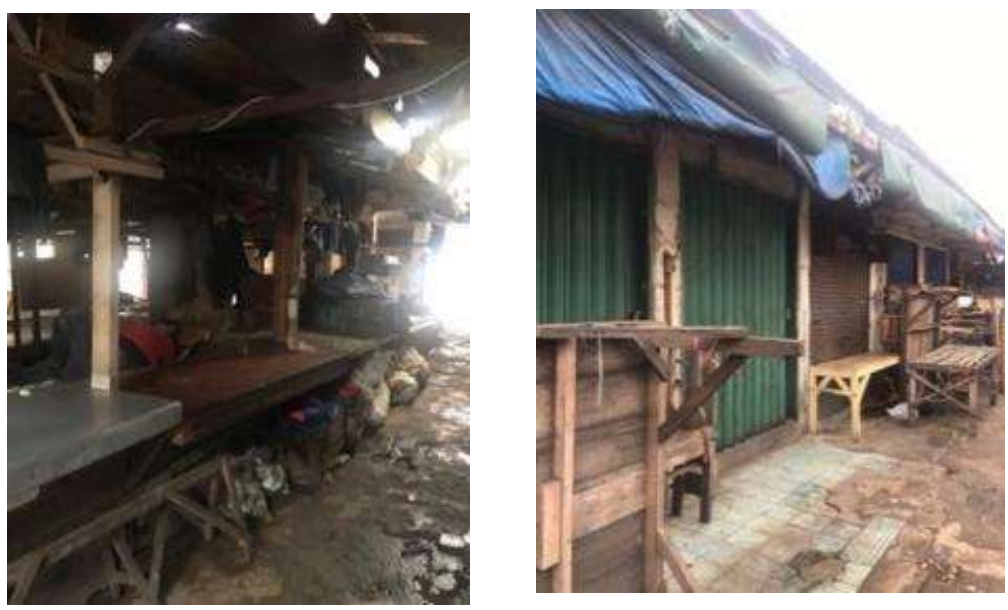

Gambar 5. Pasar dalam Kwitang Sumber: Dokumentasi Pribadi, 2020 


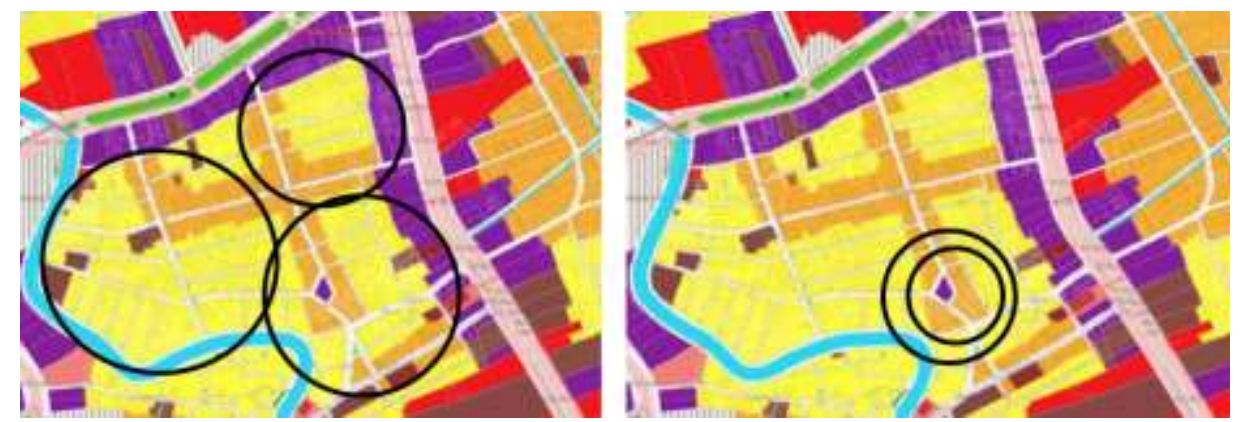

Gambar 6. Rencana Tata Wilayah dan Nodes Kawasan

Sumber: Peta Rencana Kota

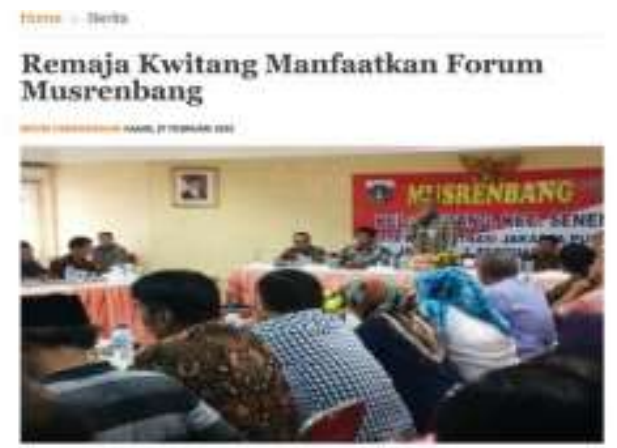

Gambar 7. Musrenbang

Sumber: https://pusat.jakarta.go.id

Tabel 1. Keberadaan Fasilitas Olahraga Menurut Kelurahan

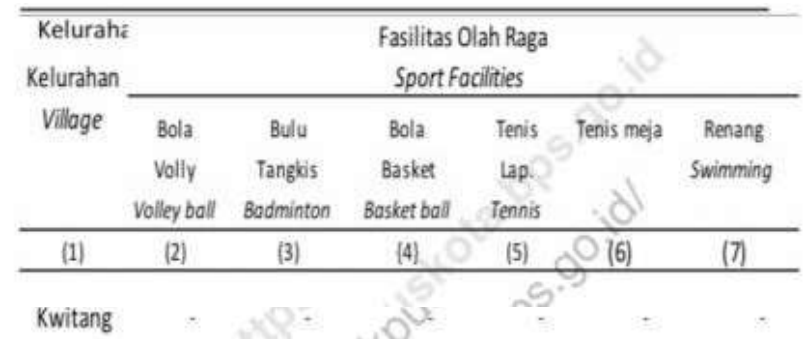

Sumber: Badan Pusat Statistik kota Jakarta Pusat

\section{Analisa Tapak Terpilih}

Pada tapak dipilih karena berada di sekitar zona perumahan yang merupakan tempat reguler orang yang berpotensi sebagai tempat yang netral dan menjadi titik berkumpul dan terjadi keramaian masyarakat. Mengambil Luas Lahan dengan peraturan zonasi KDB: 60, KLB: 2.4, KB: 4, KDH: 30 , dan KTB: 55. Pengaplikasian rancangan pada tapak sesuai dengan ketentuan lahan yaitu berada di zona campuran (Lihat Gambar 8 dan 9). Pada sisi barat tapak, merupakan perumahan dengan ketinggian bangunan 1 lantai, pada sisi timur tapak merupakan perumahan dengan ketinggian 2-3 lantai, pada selatan tapak merupakan perumahan dengan ketinggian 1-2 lantai (Lihat Gambar 10). Pada jalan sekitar tapak di lalui oleh orang yang pergi bekerja, sekolah, maupun melakukan hal lainnya, serta jalan yang dilewati untuk masuk ke perumahan. Tapak merupakan area rembesan sehingga memungkinkan untuk menjadi third place. 


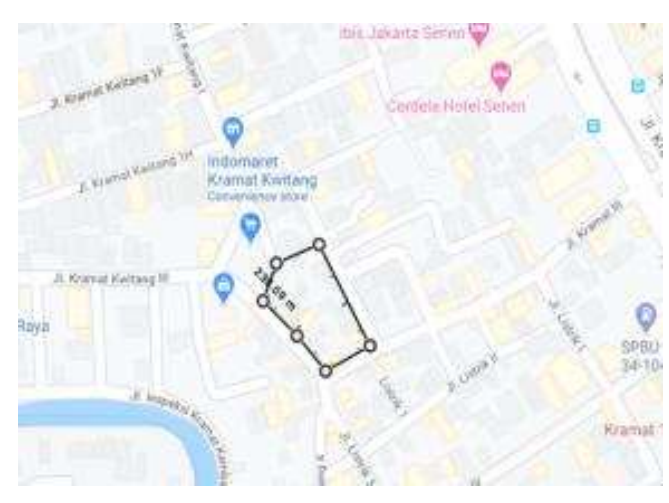

Gambar 8. Luasan Tapak Sumber: Google maps

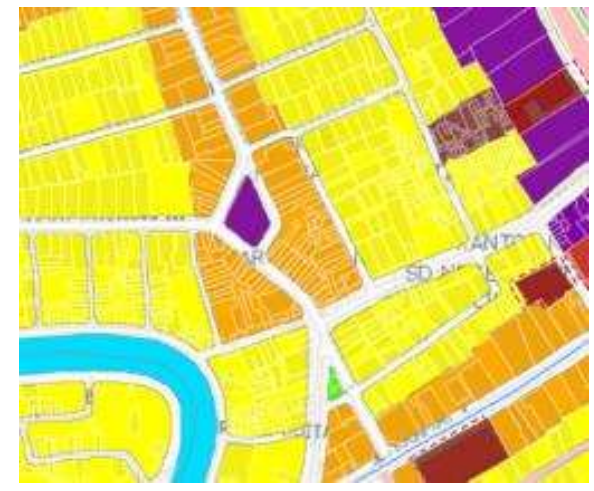

Gambar 9. Tata guna lahan Sumber: Peta Rencana Kota

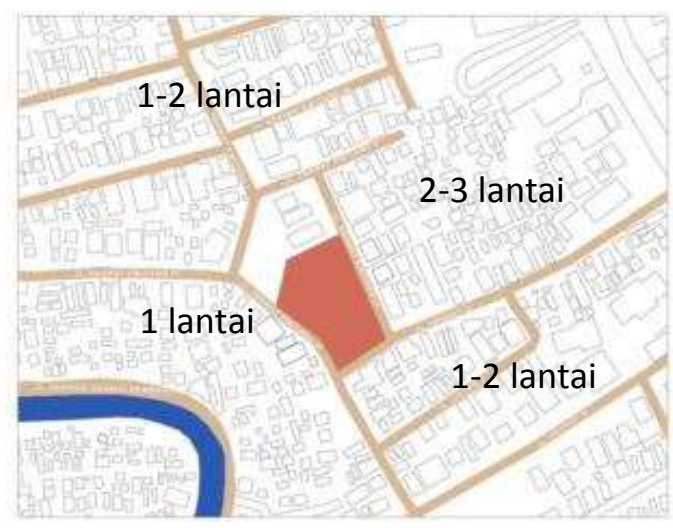

Gambar 10. Skyline Tapak

Sumber: Penulis, 2020

\section{Usulan Aktivitas dan Program Bangunan}

Usulan untuk merespons masalah, kebutuhan, dan potensi dalam lingkungan maupun masyarakat disusun kembali dengan cara menggabungkan fungsi dengan suatu konsep Cross-Programming, dikaitkan dengan kegiatan aktivitas warga bahwa terbangun atas prinsip bahwa percakapan dapat dilakukan dalam suatu ruang fisik, membawa orang masuk dan membantu mereka membangun rutinitas yang menumpuk rasa kebersamaan. program aktivitas yang diusulkan sebagai pemersatu masyarakat meliputi bersosialisasi, bertemu baik masyarakat umum maupun komunitas, sebagai tempat yang mengedukasi, kegiatan jual-beli kebutuhan masyarakat, serta menjadi ruang terbuka hijau pada kawasan.

Setelah melakukan pertimbangan pada program-program dapat menjadikan suatu wilayah yang memiliki tempat yang dapat mewadahi aktivitas masyarakat seperti pasar, taman bacaan, penjualan buku-buku (thirfts), amfiteater, workshop pada kelurahan Kwitang terutama untuk setiap lapisan masyarakat agar memiliki kualitas hidup yang lebih baik dan menjadi karakter kawasan yang merupakan penjualan buku-bukunya serta dapat mengembalikan kebutuhan untuk bersosialisasi antar sesama. 


\section{Analisis Berupa Gubahan Massa, dan Konsep Desain Bangunan}

Pada konsep desain bangunan serta gubahan massa dijalankan bersama berdasarkan konsep form follow functions. Proses gubahan massa adalah sebagai berikut: (a) Membagi gubah massa berdasarkan zoning, untuk pasar dengan area bacaan (b) Bentuk Massa menyesuaikan bentuk geometri tapak, lalu di berikan akses antar 2 jalan. Bertujuan untuk semua dapat memiliki akses untuk sampai pada tapak; (c) Neighborhood Skyline, ketinggian bangunan pada sisi utara tapak adalah 3 lantai, sedangkan pada sisi barat tapak 1-2 lantai. Maka dari itu Design bangunan akan membawa flow skyline utara ke barat; (d) Menjadikan massa yang tidak masif, sehingga dapat memaksimalkan potensi cahaya dan udara bangunan dibuat bolong untuk penggunaan energi yang tidak terlalu banyak; (e) Kedua massa menjadi satu kesatuan yang dihubungkan oleh konektor sehingga memudahkan sirkulasi mikro.

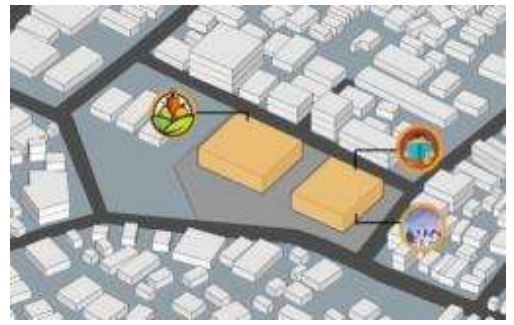

a

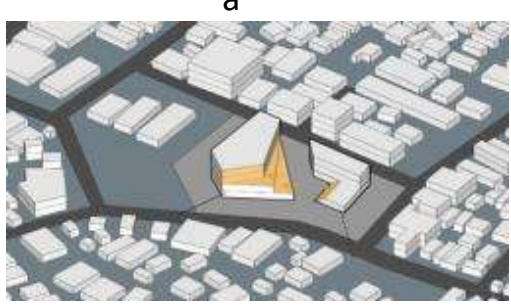

C

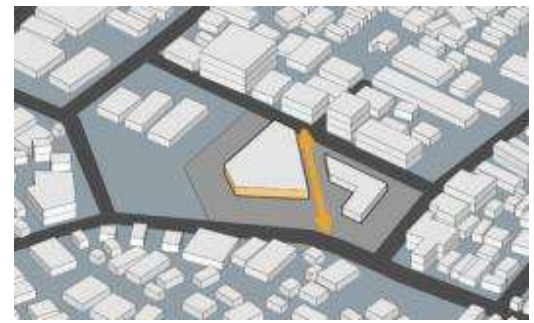

b

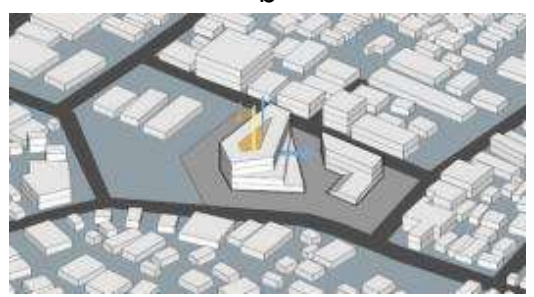

d

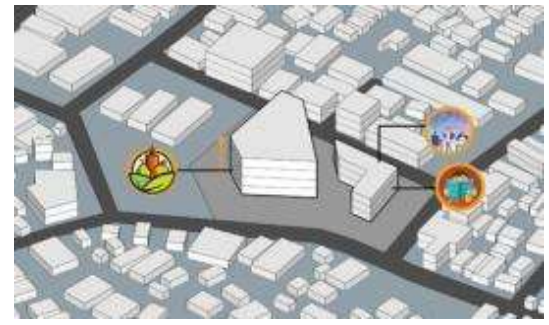

b

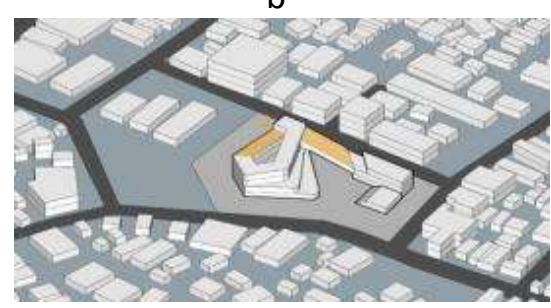

e

Gambar 11. Gubahan massa

Sumber: Penulis, 2020

Pada konsep bangunan terdapat 2 yaitu Kontinuitas jalur dan welcoming space. Pada konsep kontinuitas jalur, merupakan konsep yang digunakan untuk menguat akses koridor ataupun selasar pada pasar. Konsep bertujuan untuk mengarahkan visual pejalan kaki dalam berkeliling. Pada konsep Welcoming Space yaitu menciptakan denah yang terbuka, dan dapat diakses dari berbagai arah untuk sampai pada tapak. welcoming space mengutamakan pada user pedestrian. Selain itu bangunan proyek akan memaksimalkan dan menambah ruang terbuka hijau sehingga akan menjadi penambahan ruang hijau pada kawasan.

Mengekspresikan bentuk bangunan sesuai dengan konsep Cross Programming, membentuk bangunan dengan memikirkan program bangunan secara bersamaan dengan mengacu pada konsep perencanaan Form and Function runs together dalam wujud ekspresi bangunan sebagai wadah aktivitas ideal yang berdasarkan pada konsep Bernard Tschumi. Untuk memperkuat konsep kontinuitas jalur, Usulan penguatan jalur dengan dibuat ramp pada pasar dari lantai ke lantai atas sehingga menguatkan kesan menerus (Lihat Gambar 12). 


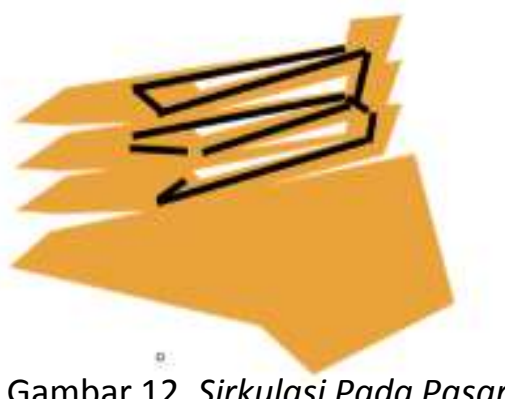

Sumber: Penulis, 2020

Selain itu konsep modular juga diterapkan pada pasar ataupun pedagang buku, seperti berikut:

\section{Modul semi permanen}

Sebuah modul yang dapat dipindah menyesuaikan kebutuhan layout pedagang (Lihat Gambar 13). Kios dipakai untuk penjualan seperti sayur, buah-buahan, dan daging. Setiap kios dapat digunakan untuk keperluan lain, seperti pada jam 7-9 pagi, digunakan untuk meletakkan dagangan seperti sayur, kemudian setelah itu sayur dititipkan bersama di Storage room lalu kemudian kios dapat digunakan untuk menjual sesuatu di jam berikutnya.
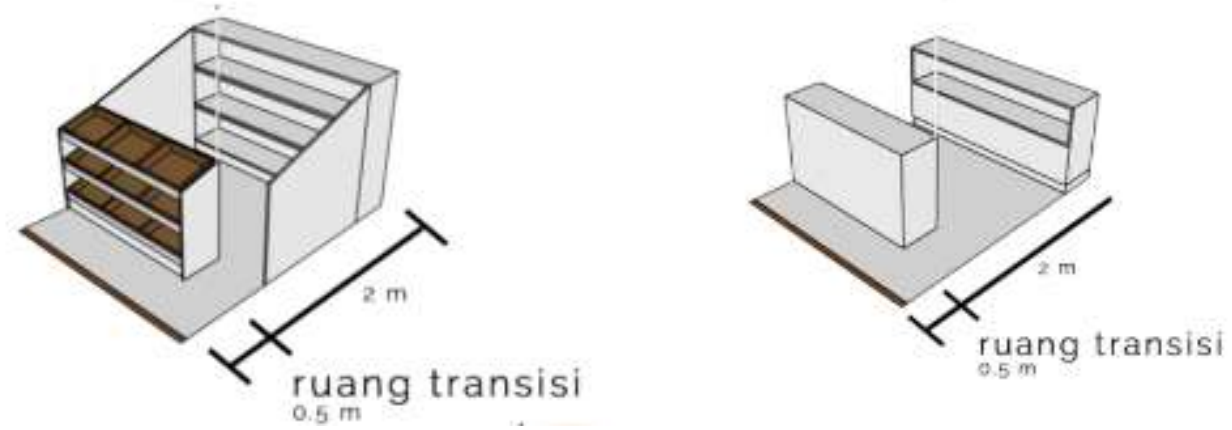

Gambar 13. Modul Semi permanen

Sumber: Penulis, 2020

\section{Modul kios semi permanen}

Ruang kios semi permanen ini memanfaatkan modul partisi sebagai batas ruangnya. Modul partisi dapat dibongkar pasang sehingga dapat menyesuaikan luasan ruang yang dibutuhkan pedagang apabila standar ruang tidak tercukupi. Satu buah partisi memiliki besar $280 \mathrm{~cm} \times 100 \mathrm{~cm}$. Modul semi permanen digunakan untuk pedagang toko kelontong pada pasar dan lantai pertama pada area pedagang buku (Lihat Gambar 14 dan 15).

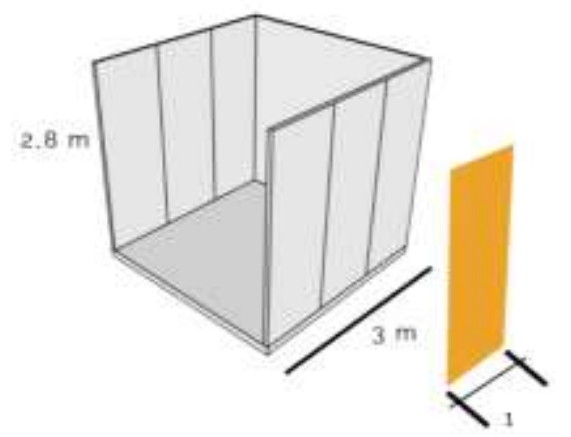

Gambar 14. Modul Semi Permanen

Sumber: Penulis, 2020 


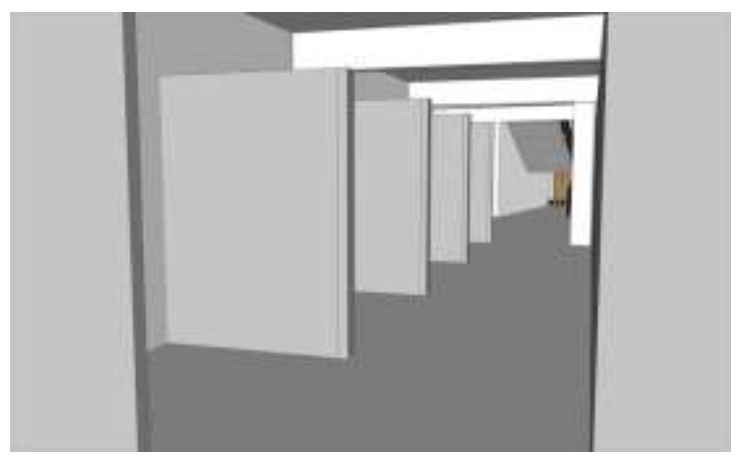

Gambar 15. Modul Semi Permanen area pedagang buku Sumber: Penulis, 2020

\section{Zoning Massa}

Zoning massa dibuat berdasarkan program yang berupa Re-desain Pasar, Taman Baca, kemudian program lainnya, Penjualan Buku-Buku (Thrifts), Education/ Workshop, Amfiteater, serta menjadi ruang terbuka hijau pada kawasan maka semua program terbagi dalam zoning tiap lantai. Pada massa pasar diletakkan dibarat tapak karena dekat dengan area jangkauan masyarakat untuk sampai ke tapak sehingga menjadi tempat reguler. Sedangkan massa area bacaan pada timur tapak diletakkan karena menjadi potensi untuk orang luar dapat sampai pada tapak karena dekat dengan akses masuk kawasan Kwitang. Namun keduanya disatukan dengan mengacu konsep Cross Programming. Pada zoning perlantai berupa: (a) lantai semi basement merupakan lahan parkir motor, loading dock, genset, area gerobak, dan area servis bangunan lainnya. Semi basement berada di bawah bangunan massa pasar; (b) Berdasarkan konsep welcoming space, akses pada lantai dasar pada bangunan terbuka, pedestrian dapat sampai tapak dari berbagai macam arah. Pada lantai dasar zoning terdiri dari pedagang buku, kiosk pasar, amfiteater dan area servis; (c) pada zoning terdapat area komunal, storage room, kelas, dan area servis; (d) pada lantai 3 terdapat area komunal, toko kelontong, kiosk, library, dan area servis; (e) pada lantai 4 merupakan area workshop, green roof pada area bacaan.
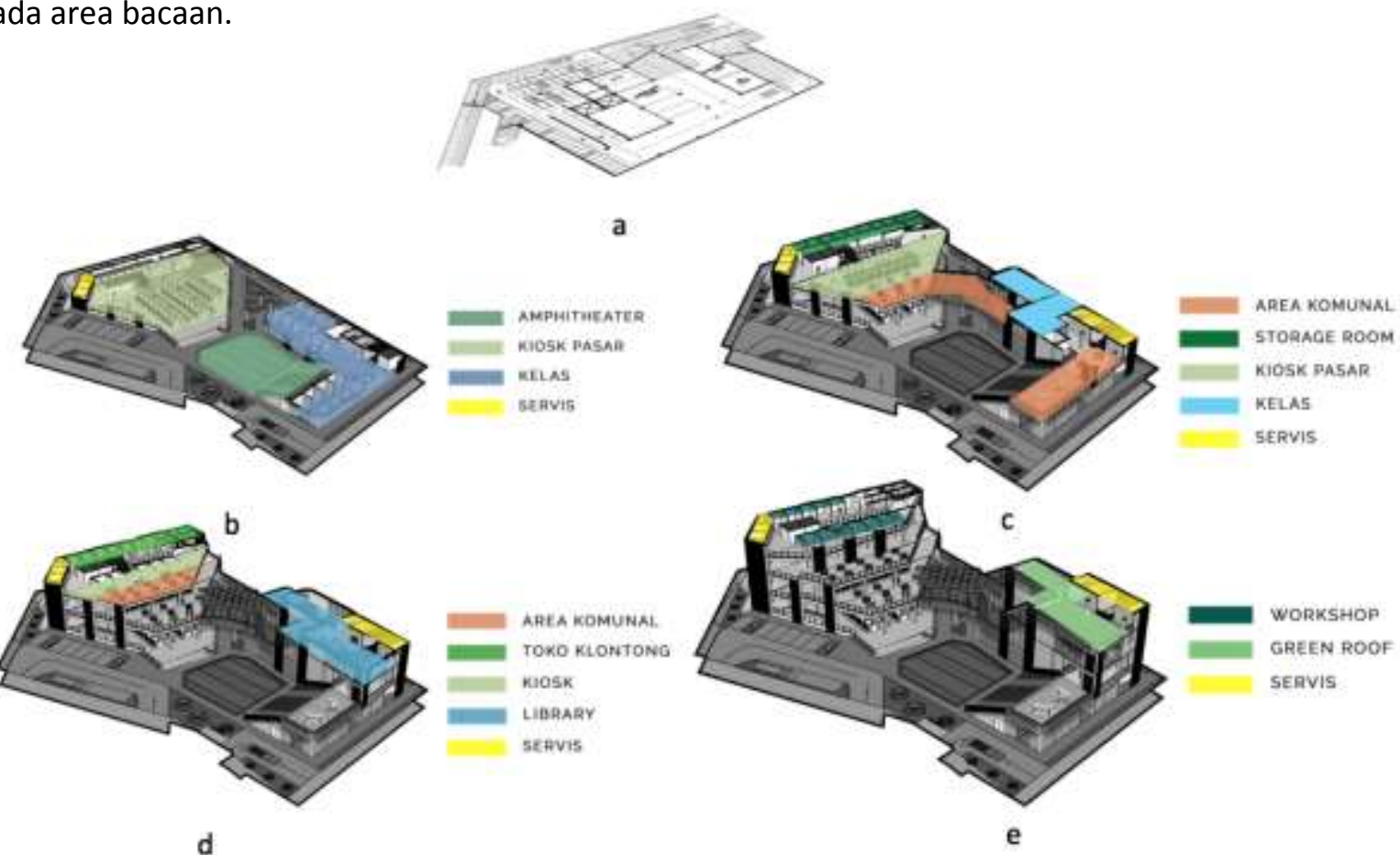

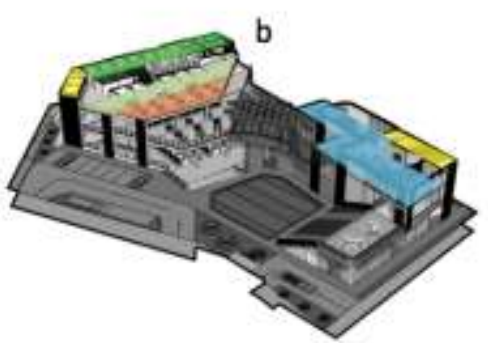

d

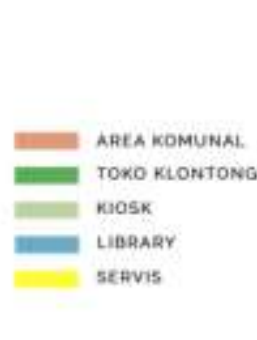

Gambar 16. Zoning Bangunan Sumber: Penulis, 2020 


\section{Materialitas}

Pada penyusun bangunan yang digunakan adalah elemen yang dipakai bangunan dengan struktur kolom beton. Pada bangunan, dibuat terbuka tidak tertutup (seperti memiliki jendela) sehingga energi pada bangunan tidak digunakan terlalu banyak serta pencahayaan alami dapat menyinari interior bangunan, dengan beberapa pertimbangan seperti penggunaan energi pada bangunan diminimalisir agar ramah lingkungan, waktu pengerjaan relatif singkat, biaya konstruksi tidak banyak seperti finishing bangunan tidak di cat, pemilihan material bangunan mudah ditemukan serta pada struktur juga tidak melenceng dari kaidah - kaidah struktural agar bangunan bisa berdiri dan digunakan.

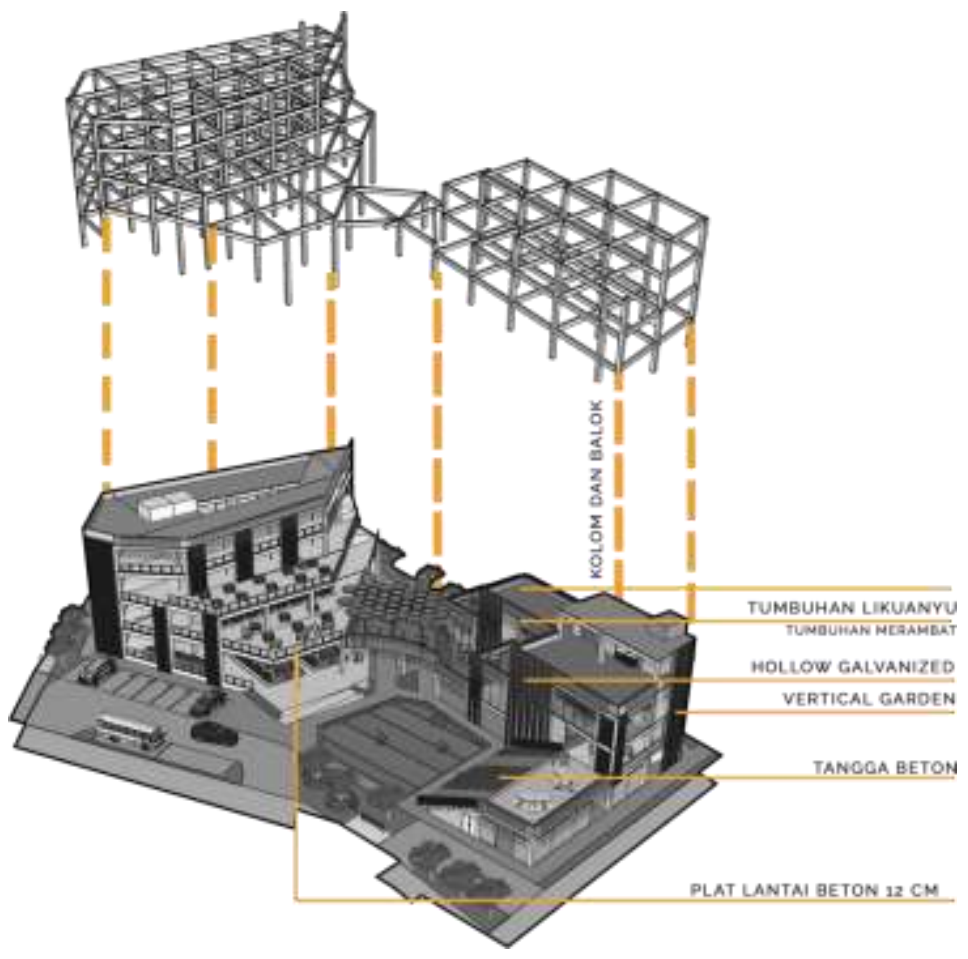

Gambar 17. Struktur dan Material bangunan Sumber: Penulis, 2020
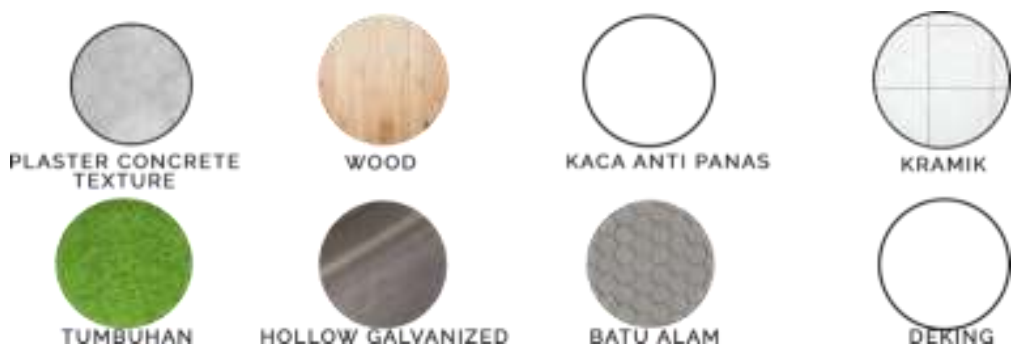

Gambar 18. Material bangunan Sumber: Penulis, 2020

\section{Bentuk Rancangan}

Bangunan pasar secara eksterior maupun interior merupakan bangunan yang terbuka, memaksimalkan potensi cahaya dan udara yang masuk pada bangunan dengan cross ventilation, Bangunan juga masih serasi dengan lingkungan serta merupakan bangunan dengan ciri dan karakter pada kawasan. Sirkulasi pada pasar yang merupakan ramp menerus dari lantai ke lantai memberi kesan kontinuitas. Sedangkan diberikan tangga agar pengunjung juga dapat langsung sampai pada lantai yang diinginkan tanpa melewati setiap ramp pada bangunan, atau juga dapat menjadi tangga sewaktu darurat. Desain pada bangunan memberikesan terbuka sehingga pada lantai 1 taman bacaan, yang merupakan pedagang buku yang dapat diakses dari berbagai arah (tidak tertutup). 


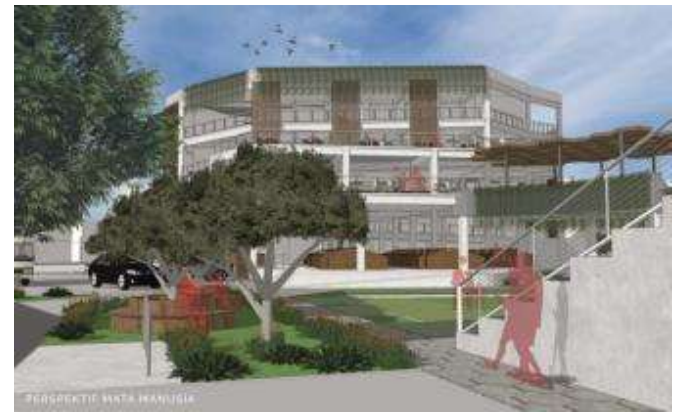

Perspektif Pasar

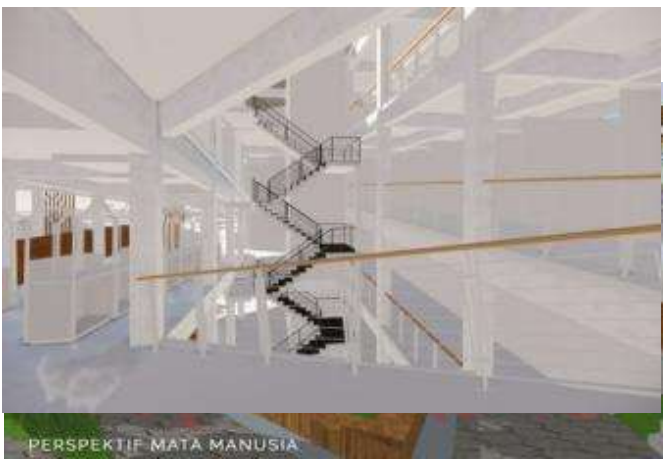

Ramp pada Interior Pasar

Perspektif Mata Manusia

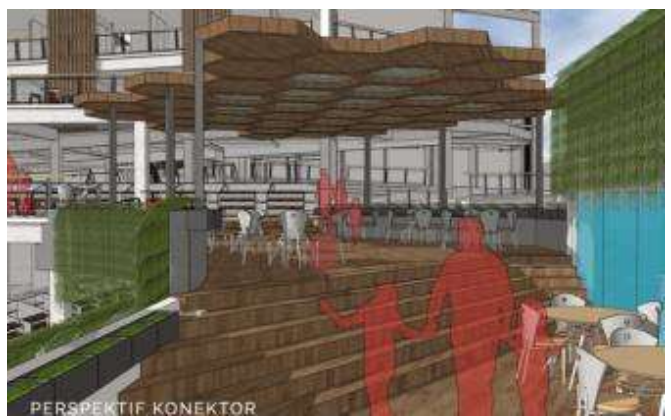

Konektor

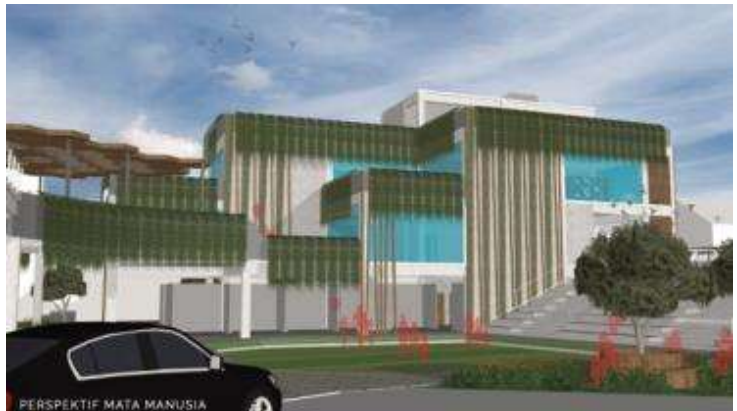

Perspektif Taman Bacaan

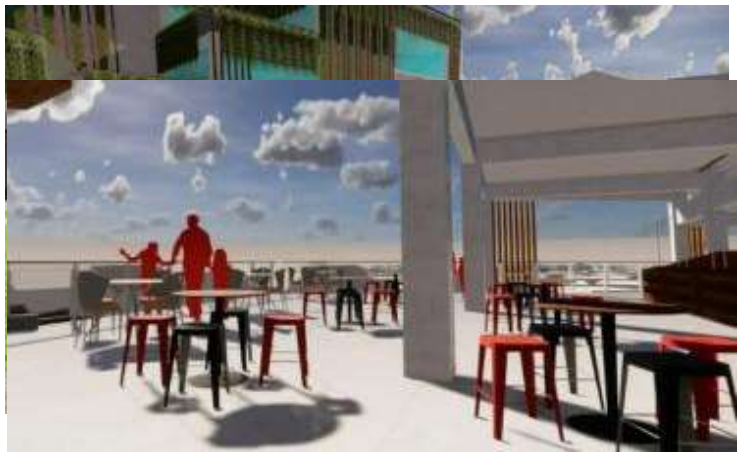

Area Komunal

Amfiteater

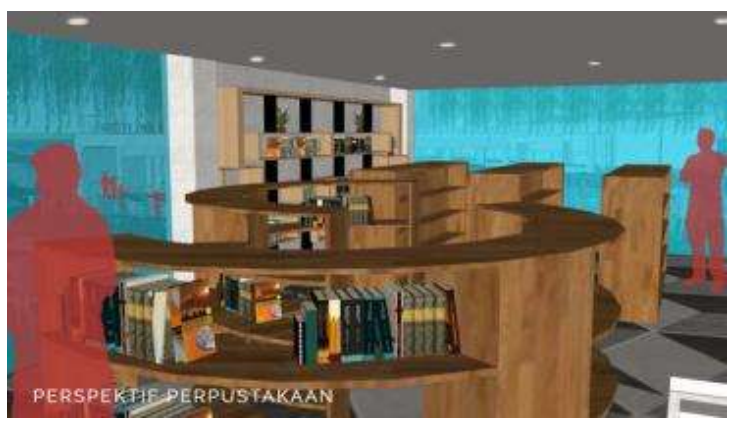

Perspektif Perpustakaan

Gambar 19. Perspektif bangunan

Sumber: Penulis, 2020

\section{KESIMPULAN DAN SARAN}

\section{Kesimpulan}

Wadah Aktivitas dan Taman Bacaan merupakan sebuah proyek yang dapat menjadikan suatu wilayah memiliki third place untuk mengatasi individualisme seperti mengembalikan rasa kebutuhan untuk saling bersosialisasi antar sesama, serta dapat mewadahi aktivitas masyarakat. Pemilihan tapak dan program didasari atas pertimbangan kebutuhan masyarakat yang dapat menjadikan suatu third place yang mampu mengakomodasi kegiatan masyarakat agar dapat menjadi kawasan yang hidup dengan bersosialisasi antar sesama. kualitas hidup yang lebih baik. Serta memiliki kekhasan wilayah Kwitang yang dikenal dengan penjualan buku-bukunya.

Konsep perancangan pada Wadah Aktivitas dan Taman Bacaan ini menggunakan metode Cross Programming dengan Form and Function Runs Together menjadi panduan untuk membentuk gubahan massa proyek ini sambil memikirkan konsep program pada saat yang bersamaan. Program 
pada proyek ini dikaji berdasarkan kebutuhan seperti Analisis Lokasi serta potensinya; Analisa Tapak Terpilih; Usulan Aktivitas dan Program Bangunan; Analisa Konsep; Analisis perancangan berupa Gubahan Massa, Konsep desain bangunan; lalu kemudian Zoning Massa dan Hasil akhir berupa materialitas, Bentuk Rancangan berupa desain eksterior dan interior bangunan.Program berupa Redesain Pasar, Taman Baca, Penjualan Buku-Buku (Thrifts), Education/ Workshop, Amfiteater, serta menjadi ruang terbuka hijau pada kawasan. Melalui proyek ini, pengunjung datang diberi kesan terbuka sesuai dengan konsep welcoming space yang di usulkan berupa denah yang dapat diakses dari berbagai arah menjadikan tapak area rembesan, dan konsep kontinuitas berupa ramp pada pasar yang menerus dari lantai ke lantai memberi kesan yang baru dan interaktif bagi masyarakat. Dapat diterapkan dan di sesuaikan dengan kebutuhan dan keinginan penduduk dalam menghasilkan sebuah 3rd Place sebuah kawasan Kwitang.

\section{Saran}

Dengan kehadiran third place di Kwitang, maka diharapkan bagi para perancang dan mahasiswa arsitektur agar dapat merancang sebuah bangunan yang mampu mewadahi segala kebutuhan penggunanya yang tak dipandang berdasarkan tingkatan sosial, menjawab permasalahan terutama dalam sosialisasi, hubungan interaksi atau timbal balik baik di lingkungan atau antar manusia.

\section{REFERENSI}

Bintarto, R. (1984). Interaksi desa-kota dan permasalahannya . Jakarta: Ghalia Indonesia.

Dwiyantoro. (2019). Peran Taman Bacaan Masyarakat Mata Aksara dalam menumbuhkan minat baca pada masyarakat. Jurnal Kajian Informasi \& Perpustakaan .

Gehl, J. (2011). Life Between Buildings: Using Public Space. Washington: Island Press.

Kominfotik, 2019, diunduh 2020, (https://pusat.jakarta.go.id/?berita=Remaja.Kwitang.Manfaatkan.Forum.Musrenbang\&web\& mod=ful Imain\&section=info\&action=news\&id=0000003772

Oldenburg, R. (1999). The Great Good Place: Cafes, Coffee Shops, Bookstores, Bars, Hair Salons, and Other Hangouts at the Heart of a Community. USA: Marlowe \& Company.

Prasetya, A. I., 2019, diipetik 2020, dari Detik.com: https://news.detik.com/berita/d4372673/pedagang-buku-di-kwitang-dan-senen-bertahan-di-era-online

Project for Public Spaces. (t.thn.). Diambil kembali dari PPS.com: https://www.pps.org/article/grplacefeat?

Trisno, R., \& Lianto, F. (2019). Relationship Between Function-Form in the Expression of Architectural Creation, 1-6.

Tschumi, B. (t.thn.). Theory of Contenporary Architecture. Diambil kembali dari https://tocapu2017.wordpress.com/2017/10/11/bernard-tschumi/

Wikipedia. (t.thn.). Diambil kembali dari https://id.wikipedia.org/wiki/Pasar_tradisional

Zhang, \& Lawson. (2009). Meeting and Greeting : Activities in public outdoor spaces outside high density urban resindential communities. 
